\title{
K. Perumpallikunnel
}

\section{DISCERNMENT: THE MESSAGE OF THE BHAGAVAD-GITA}

\section{ABSTRACT}

The Bhagavad-Gita is an intelligent response to a perennial human predicament which other religions and philosophies also tried to resolve in their own way. Human beings often stood perplexed and mystified as they confronted paradoxical situations in life that demanded action. Discerning right from wrong often became an existential predicament. The Pandava prince Arjuna found himself standing on the shaky ground of Kurukshetra not knowing the way forward. Lord Krishna outlines for him the path towards gaining flawless self-knowledge and self-mastery from his sorrowful state of confusion and opened his eyes to perceive the truths beyond appearances. Krishna instructs him that, when a person is capable of watching everything that happens within and around him dispassionately and acting with an attitude of detachment, he attains sthithaprajna (equanimity) and samadhai (liberation).

\section{INTRODUCTION}

The subject matter of the Bhagavad-Gita (The song of God) is nothing other than discernment (Ramacharaka 2010:3). According to the Gita, discernment is all about nityanithya vastu viveka (discernment of the eternal and temporal realities) (Kaji 2001:27). Lord Krishna, the supreme Guru, tutors his confused disciple, Arjuna, to lead him from the state of maya (illusion) to the perfect understanding of satyasya satyam (really real). Krishna outlines for Arjuna the path towards gaining flawless selfknowledge and self-mastery from his sorrowful state of confusion (1:47). Being a part of the epic Mahabharatha, which falls under the category of ithihasas (epics), the Bhagavad-Gita technically belongs to the smrti literature (recollected/reflected/remembered: all human wisdom and knowledge belong to this category). However, since it is the utterance of the incarnated God Lord Krishna himself, the Bhagavad-Gita is approved as a part of shruti (heard/revealed: Vedas and Upanishads) and is often

Dr K. Perumpallikunnel, Research Fellow, Department of New Testament, University of the Free State, Bloemfontein. E-mail: kurcmi@gmail.com. 
called Gitopanishad. ${ }^{1}$ According to its devotees, the Bhagavad-Gita is the essence of the Vedic knowledge and one of the most important Upanishads in the Vedic literature.

The Bhagavad-Gita was written to lead Arjuna from the slavery and obscurity of avidya (ignorance) to the freedom and splendour of jnana (wisdom). Moksha (liberation/enlightenment) is the purging of the illusory thoughts and beliefs about this transitory world - thus entering a state of pure consciousness and realising and accepting reality as it is. The instructions of the Bhagavad-Gita are designed to awaken this pure consciousness; therefore, in the final section of the Gita, Krishna asks Arjuna if he is now in pure consciousness (18:72). Pure consciousness is being in a state of samadhi (equanimity), being in control of one's mind and body. Impure consciousness is a state of being blinded and disturbed by the ego. In the last section of the Bhagavad-Gita (18:66), the Lord Krishna reiterates sarva-dharman parityajya, mam ekam saranam vraja, aham tvam sarva-papebhyo, mokshayisyami ma suchah. (Abandon all religions [beliefs and concepts] and take recourse in me. I shall liberate you from all sins. Do not be afraid.) Many people such as Mahatma Gandhi found solace in this Celestial Song:

When doubts haunt me, when disappointments stare me in the face, and I see not one ray of hope on the horizon, I turn to the BhagavadGita and find a verse to comfort me; and I immediately begin to smile in the midst of overwhelming sorrow. Those who meditate on the Gita will derive fresh joy and new meanings from it every day.

\section{THE MAHABHARATHA: THE GREATEST EPIC EVER WRITTEN}

The Mahabharata, often known as the Hindu bible, is the story of a great war. It is one of the two Sanskrit epic poems of ancient India (the other being the Ramayana). The poem is made up of nearly 100000 couplets (approximately seven times the length of the Iliad and the Odyssey combined or 12 times the length of the Bible) or approximately 1.8 million words in total. Its authorship is traditionally ascribed to the sage Vyasa, although it is unlikely that a single person wrote the poem (Chaturvedi 2006:24). The author Vyasa himself appears in the work as the grandfather of the Kauravas and the Pandavas. The Mahabharata not only displays a riveting plot and a compelling dramatic structure, but is also full of

1 Even in the Gita, at the end of every chapter, while assigning a title to each, the catechesis of Krishna is mentioned as Gitopanishad. 
wisdom. Its characters are complex and real, with depth of personality that is unmatched in any other story humanity has ever conceived. The Mahabharata contains numerous mythological and didactic material arranged around a central heroic narrative that tells of the struggle for sovereignty between the Kauravas and the Pandavas. The traditional date for the war that is the central event of the Mahabharata is $1302 \mathrm{BCE}$, but most historians assign it a later date. The best scholarly evidence indicates that the earliest layers of the epic were composed between 2500 and 3000 years ago. The oldest preserved parts of the text are not thought to be appreciably older than $400 \mathrm{BCE}$, although the origins of the story probably fall between the 8th and the 9th centuries BCE. The text reached its present form by 300-400 CE. According to the Mahabharata itself, the tale is an extended text from a shorter version of 24000 verses called simply Bharata. The present poem is divided into 18 books or parvas.

The central plot constitutes little more than one fifth of the epic. The remainder of the epic addresses a wide range of myths and legends. Besides its epic narrative of the Kurukshetra War and the fate of the Kauravas and the Pandavas, the Mahabharata contains a great deal of philosophical and devotional material. The Mahabharata itself proclaims its comprehensiveness confidently:

As the sun dispels the darkness, so does the Mahabharata by its discourses on religion, profit, pleasure and final release, dispel the ignorance of men (1.1.73).

He who knows the four Vedas with all the Angas (subdivisions) and Upanishads, but does not know this history (Mahabharata), cannot be regarded as wise ... As the formation of the three worlds proceeds from the five elements, so do the inspirations of all poets proceed from this excellent composition (1.2.572).

The Mahabharata uttered by the lips of Dwaipayana is without a parallel; it is virtue itself and sacred (1.2.584).

The Mahabharata incorporates most of the lore and legend of the Classical Hindu Tradition (Ganguli 2012). It is a plot large enough to encompass all categories, yet it is not a random collection of tales. Every story in the Mahabharata sheds light on the central story which is the great battle that was fought on the field of Kurukshetra between the five sons of King Pandu and their allies, on the one hand, and the hundred sons of King Dhritarashtra and their allies, on the other. The war broke out. And it was devastating. In its plain sense, it was a tragic war that pitted brothers against brothers, sons against fathers and uncles, brave noble men against brave noble men. Though initially keeping to chivalrous notions of warfare, both sides soon began adopting disreputable tactics. At the end of the 
ferocious 18-day battle, though the Pandavas and Krishna managed to survive, it was not a victory for them, for the war had destroyed the world that they knew, and the emptiness of what they had won tainted the rest of their lives. After "seeing" the carnage, Gandhari ${ }^{2}$ who had lost all her sons, cursed Krishna to face a similar death and to witness an equivalent eradication of his own family for, although divine and capable of stopping the war, he did not do so. Krishna accepted the curse, which befell on him in the course of time. The Pandavas who gained their kingdom through bloodshed and fratricide chose to renounce everything and set off on a pilgrimage to Indraprasta (heaven), their destiny. On the way, one by one the brothers and Draupadi, their wife ${ }^{3}$ fell. As each one fails, Yudhishtira (the elder brother) gave the other brothers the reason for their fall (Draupadi was lenient towards Arjuna, Nakula and Sahadeva who were vain and proud of their looks, and Bhima and Arjuna were proud of their strength and archery skills, respectively). Only the virtuous Yudhishtira, who had tried everything to prevent the carnage, and the stray dog that joined the group prevailed. The dog reveals itself as Yama (god of death/underworld), and then takes Yudhishtira to the underworld where he sees his siblings and wife. After explaining the nature of the test, Yama takes Yudhishtira back to heaven and explains that it was necessary to expose him to the underworld, because any ruler has to visit the underworld at least once (Rajyante narakam dhruvam). Yama then assures him that his siblings and wife would join him in heaven after they had been exposed to the underworld for measures of time according to their vices (Nadumuri 2010).

\section{THE BHAGAVAD-GITA: THE TEXT}

The Bhagavad-Gita opens with the blind King Dhritarashtra requesting his secretary, Sanjaya, to narrate the battle between his sons, the Kauravas, and their cousins, the Pandavas (1:1). Out of affection for his devotee, the Pandava prince Arjuna, Lord Krishna, the mighty incarnation of Vishnu, one of the Hindu Trinity (the others being Brahma and Siva), agreed to drive his chariot. As Arjuna takes up his bow and prepares to fight, he faces his great-grandfather Bhishma and his teacher Drona on the other side with the sons of Dhritarashtra (1:26). His mind reels as he foresees the imminent death of his teachers, relatives, and friends (1:45). Developing doubts about the battle, he requests the glorious Krishna to draw his

2 The Queen Gandhari, the mother of Kauravas, blindfolded herself when she wed the blind king Dhritarashtra and opted for "blindness" all through her life.

3 Draupadi was the wife of all the five Pandava brothers, as mandated by their mother Kunthi. 
chariot between the two fighting forces (1:24). From there he observes the imminent devastation. Overtaken by grief, he lays down his weapons and decides not to fight (1:47). In that decisive moment, Krishna delivers his magnificent instruction to enlighten and embolden him to wake up to his call of duty.

\section{THE APPEAL OF THE GITA}

The Bhagavad-Gita is thoroughly practical and free of any intellectual gymnastics, or vague, abstract philosophy. It offers diagnostic solutions to every challenging situation that we face in our daily life that calls for discernment and action. The Gita is not rigid either. At the end of his instruction, Krishna tells Arjuna:

Now I have taught you that wisdom which is the secret of secrets.

Ponder it carefully. Then act as you think best (18:63).

No coercion, no promises, no threats. It is up to the listener to decide. The Gita simply shows us the way forward.

\section{THEMES OF THE EIGHTEEN CHAPTERS OF THE BHAGAVAD-GITA}

Just as the epic Mahabharata contains 18 books that narrate a war that was fought between 18 Akshuhinis $^{4}$ for 18 days, the Gita also contains 18 chapters. Each chapter is envisioned as a kind of yoga in itself. The function of yoga is to train our body and mind until it reaches samadhi (equanimity/liberation/enlightenment). The chapters have a progressive order to their teachings, whereby Krishna raises Arjuna up the ladder of yoga one rung at a time. According to the Bhagavad-Gita, every aspect of our life can be salutary, even those aspects that seem negative.

- Chapter 1: Arjuna-Vishada yoga (The yoga of the dejection of Arjuna) - 47 verses. Arjuna's depression is presented as a system of yoga. When Arjuna sees his near and dear ones on the opposing army side of the Kurus, he loses morale and decides not to fight (1:20-27). Arjuna

4 An Akshauhini was an ancient battle formation that consisted of 21870 chariots; 21870 elephants; 65610 cavalry and 109350 infantry as per the Mahabharata (Adi Parva 2.15-23). The ratio is 1 chariot : 1 elephant : 3 cavalry : 5 infantry soldiers. In each of these large number groups (65610, etc.), the digits add up to 18 . 
presents Krishna his arguments for refusing to fight (1:28-47). Basically, he fears the sinful reactions of killing.

- Chapter 2: Samkhya Yoga (The yoga of knowledge) - 72 verses. Concluding his reasoning and yet confused, Arjuna turns to Lord Krishna for discernment (2:7). Krishna begins countering Arjuna's objections. Krishna tells Arjuna that the eternal self is immortal and the body is designed to pass away (2:12-30). Explaining the three principles dharma, (right action) atman (individual self) and sarira (body), Krishna reminds Arjuna that, as a warrior, his duty is to uphold the path of dharma through warfare (2:31-38).

- Chapter 3: Karma Yoga (The yoga of action) - 43 verses. Confused by listening to Krishna's exaltation of samkhya (jnana) yoga (The yoga of knowledge), Arjuna questions why he should engage in fighting if knowledge is more important than action (3:1-2). Krishna then explains nishkama karma (performing one's duties without desiring its fruits - detached activity) as the appropriate course of action (3:3-8). He explains that both improper action and neglect of duty are impelled by desire and lack of knowledge. Krishna counsels Arjuna to act with knowledge and detachment without falling victim to his own attractions and aversions (3:29-30).

- Chapter 4: Jnana-Karma-Sanyasa Yoga (The yoga of knowledge, discipline of action and knowledge) - 42 verses. Krishna reveals to Arjuna his many incarnations for the defence of the virtuous and the destruction of the wicked (4:7). The chapter ends with Krishna glorifying transcendental knowledge and appealing to Arjuna to arm himself with this knowledge, which burns the evil effects of every action to ashes (4:33-42).

- Chapter 5: Karma-Sanyasa Yoga (The yoga of action and knowledge) 29 verses. Arjuna wants to know if it is better to renounce action or to be involved in action (5:1). Krishna answers that one who is detached from his works' fruits is the one who is truly detached $(5: 2-6)$. He will be in a position to see action in inaction and inaction in action (4:18). Such a person knows that, while the body acts, he, the soul, actually does nothing (5:7).

- Chapter 6: Dhyana Yoga, or Atmasamyama Yoga (The yoga of selfcontrol) -46 verses. Krishna explains the correct posture for meditation (6:11-15) and how to achieve samadhi (6:24-27). 
- Chapter 7: Jnana-Vijnana Yoga (The yoga of knowledge of Nirguna Brahma and manifest divinity) -30 verses. Krishna instructs the path of knowledge (Jnana Yoga).

- Chapter 8: Akshara-Brahma Yoga (The yoga of indestructible Brahma) - 28 verses. Krishna tells Arjuna that, by remembering him at the time of death, one can attain his supreme abode (8:5-7). He pinpoints devotion towards him as the easiest way to attain liberation (8:14).

- Chapter 9: Raja-Vidya-Raja-Guhya Yoga (The yoga of the sovereign science and the sovereign secret) - 34 verses. Krishna discloses to Arjuna how all beings find their existence in him (9:4-8). He reveals his self, although independent and aloof, as that which pervades, creates and annihilates the entire cosmos through his material energy (9:9-10). This awareness is recommended as a way to remember him in all circumstances. Krishna affirms that he will take care of his devotees, compensate for their deficiencies, and preserve their strength. And all he asks of his devotees is an offering of a leaf, a flower, or some water - if it is offered with devotion (9:26). Even if a devotee unintentionally commits a dreadful sin, he will be rectified, for Krishna promises that his devotee will never perish (9:30).

- Chapter 10: Vibhuti-Vistara-Yoga (The yoga of divine glories) - 42 verses. Krishna explains his grandeur more specifically and thereby reveals himself the Supreme Personality of Godhead, the source of all $(10: 2-8)$. Krishna also tells how his pure devotees know that he is the unborn Supreme Lord, the source of all sages, the source of the material and spiritual worlds, and the source of all qualities and attitudes. Arjuna recognises Krishna as the Supreme Being, as the great sages have done in the past.

- Chapter 11: Visvarupa-Darsana Yoga (The yoga of the vision of the universal form) -55 verses. On Arjuna's request, Krishna displays his visvarupa (universal form), a theophany of a being facing every way and emitting the radiance of a thousand suns, containing all beings and substances in existence (11:9). In this astounding effulgent, allexpansive form, Arjuna sees all soldiers on both sides dying within it (11:10-30). Krishna explains his form as time, the destroyer of all worlds, and requests that Arjuna, knowing in advance the inevitable death of all the warriors, become his instrument (11:32-34).

- Chapter 12: Bhakti Yoga (The yoga of devotion) - 20 verses. It describes Bhakti Yoga in detail. Krishna extols the benefits of devotion (12:1-12). $\mathrm{He}$ also explains different forms of devotions and spiritual disciplines. Arjuna inquires whether it is better to worship Krishna (incarnate God) 
through devotional service or the impersonal God (Ningana Brahma). Krishna clarifies that one who is engaged in active service is the highest (12:20).

- Chapter 13: Kshetra-Kshetrajna Vibhaga Yoga (The yoga of discrimination between the field and the knower of the field) - 34 verses. Krishna describes the human body as kshetra (temple/field), stating that one who knows this fact is a kshetrajna (knower) (13:1-18). Krishna describes prakrti (nature/matter), the purusha (enjoyer/spirit) and consciousness (13:19-34). Unassumingly advancing in knowledge, one can become free from worldly entanglement.

- Chapter 14: Gunatraya-Vibhaga Yoga (The yoga of classification of the three gunas) - 27 verses. Krishna explains the three gunas (qualities/ traits) of material nature, namely satvaguna, rajoguna and tamoguna (goodness, passion and ignorance), respectively (14:5-10). These three forces control all conditioned persons within this world. A discerning person is of satva nature (14:11). It is possible to transcend the bondages of these gunas through devotion (14:26).

- Chapter 15: Purusottama Yoga (The yoga of the supreme person) 20 verses. It explains the ways and means to free oneself from the grip of the three gunas of matter. Krishna compares the material world to a gigantic banyan tree with its roots in the heavens and its foliage on earth. Krishna invites Arjuna to fell this tree with the "axe of detachment", in order to progress towards his supreme abode (15:3).

- Chapter 16: Daivasura-Sampad-Vibhaga Yoga (The yoga of discrimination between the divine and the demonical properties) -24 verses. Krishna indicates the divine and the demonic traits present in human nature. After mentioning twenty-six godly qualities, Krishna explains the demoniac nature which degrades the soul through arrogant, ignorant, and conceited pursuits of sense gratification and power (16:1-18). He counsels that, in order to attain the supreme destination, one must give up lust, anger and greed (16:21-22). Assisted by buddhi (intellect) and supported by scriptural confirmation, one should discern right and wrong and act appropriately (16:24).

- Chapter 17: Sraddhatraya-Vibhaga Yoga (The yoga of the classification of the threefold faith) - 28 verses. Krishna mentions three divisions of beliefs, thoughts, deeds and even eating habits corresponding to the three gunas (17:4-10).

- Chapter 18: Moksha-Sanyasa Yoga (The yoga of liberation through the path of knowledge and self-surrender) - 78 verses. It is a review of the 
truths already presented (18:6). In conclusion, Krishna advises Arjuna to abandon all forms of dharma and simply surrender unto him (18:66). $\mathrm{He}$ describes this as the ultimate perfection of life. After listening to the instructions of Sri Krishna, Arjuna is confirmed and gets ready to fight (18:73). After narrating this conversation to Dhritarashtra, Sanjaya regards Krishna with enormous admiration and predicts victory for Arjuna, the supreme archer, for he is surrendered to Krishna, the master of all mystics (18:78).

\section{SYMBOLISM OF THE BHAGAVAD-GITA}

Some people insist that Sacred Scriptures can have only one meaning and, therefore, eschew interpretations and even translations (Frein 2012:12). However, this is a mistaken assumption with regard to the Hindu Sacred Scriptures in Sanskrit. Hindu scriptures are intended to have multi-level messages and subtle nuances. Their literary style (sutras and shlokas: aphorisms and versifications) demands, necessitates, and provides room for any number of commentaries and interpretations. Words that carry several relevant ideas are ideal for the profound wisdom of the Gita and the Upanishads, in particular. The Hindu scriptures consist of unlimited layers, many symbolic in nature (Knapp 2012). In addition, the meanings of the symbols are not fixed. They may change according to the level on which they occur.

While attempting to explore the allegorical realms of the BhagavadGita, we should not fail to notice a metaphor portrayed in the first chapter of the Kathopanishad: ${ }^{5}$

Body is the chariot, soul the traveler, intellect the charioteer, mind the bridle, five senses are five horses, while desires are the paths on which those horses gallop. (Kathopanishad 1:3:3, 4).

Over the centuries, numerous attempts have been made to figure out and attribute symbolic meanings to the events and personalities in the Bhagavad-Gita. Leaving aside the complex issue of assigning symbolic meanings to every person named in the battle narrative, it is not difficult to figure out the basic symbolism. This world in which we live is a

5 The Kathopanishad is a widely known Upanishad and is counted among the principal Upanishads. It consists of two chapters, each divided into three sections that contain between 15 and 29 verses. It belongs to the Black Yajurveda. It was likely composed after the fifth century BCE. Central to the text is the story of Nachiketa, son of sage Vajasravasa, and his encounter with Yama, the Hindu God of death. 
dharmakshetra, a field upon which we act out our svadharma (vocation/ duty/inherent obligation) according to our character or our innate constitution. The quality of our emotions, mind, intellect, and will depends on our present level of evolution. It is not merely in the world, but even within ourselves that we find all kinds of negative impulses, conflicts, confusions, fears, and ignorance. Although, at times, deep within ourselves, we could sense an attraction towards divinity, it is often overruled by a multitude of impulses to delusion. However, it is to be noted that all the warriors of ignorance and delusion are children of a blind ego (Dhritarashtra), whereas the inner soldiers of truth and higher consciousness are the children of the Spirit-Self, the divine Atman. Kurukshetra is the personality. Buddhi (mind/intellect) of the individual is the charioteer who tries to lead the true self to attain enlightenment. This aspiration for truth evokes opposition from within one's own mind and body, governed by the blind ego. Thus begins the war between Pandavas and Kauravas, good and evil, truth and falsehood, ignorance and wisdom, trying to annihilate each other. The most surprising feature of this inner war is that many insightful and honest "virtues" are lining up in support of the "worthless". For example, the ego, which is the creation of ignorance and delusion, torments the individual self as a result of his/her fears, desires and illusions. It manages to line up the bona fide human qualities to defend and ensure its survival under the pretext that the individual's survival is intertwined with his/her own survival. Individuals who use their intellectual faculties to achieve the goals dictated by their blind instincts are yet another example of this phenomenon. As a result, along with the Kauravas, most of the "Pandava" army is also eliminated in the eventual transformation of the individual into a higher state of being.

Krishna (literally, the dark one) and Arjuna (literally, the white one) represent the unknown and the known (God and human person), as well as our own dual nature as immortal and mortal. From this standpoint, the dialogue between Krishna and Arjuna can be regarded both as God's communication to human beings and the communication of our own divine Self with our human self, the intention of which is moksha/samadhi or liberation from sufferings (equanimity). Accordingly, Arjuna and Krishna are the indwelling atman (individual self) and Paramatman (immortal self) riding the chariot, which is Arjuna's body. The Mundakopanishad speaks of two birds of golden plumage; inseparable companions, the individual self and the immortal self, as perched on the branches of the same tree. The former tastes of the sweet and bitter fruits of the tree, whereas the latter, tasting of neither, calmly observes. The individual self, deluded by forgetfulness of its identity with the divine self, bewildered by its ego, grieves and is sad. However, when it recognises Paramatman as its own 
true self, and beholds its glory, it grieves no more (Mundakopanishad 3:1:1, 2). These verses are a perfect summary of the Gita. Arjuna is the bewildered and sorrowing atman, the individual self, and Krishna is the divine Paramatman, the supreme self from which the atman derives its very being and existence. Forgetful of its true nature as part of the cosmic/universal/immortal self, the finite atman passes through countless experiences that confuse and pains it, producing utterly false conclusions that compound and perpetuate the illusion and sorrow. Only when the perspective of the divine self is entered into, will its plight fade away.

The ego (blind Dhritarashtra) is the false self that reigns on the throne of our body and mind, blinding us to everything else, and making us think that it is the essence of our being. However, this is not true. Buried deep within us is our true self, awaiting its liberation and the recapturing of its rightful kingdom. Duryodhana (dirty fighter), the elder son of Dhritarashtra (one who holds the kingdom), is a dangerous evolution of his blind father since he is no longer blind. He is capable of consciously choosing evil if he believes that it serves his ambition. He is coercing the virtuous to commit self-sacrifice in order to gratify his hunger for power. This shows that the virtues serving the ego and working to ensure its preservation are certainly risking their lives. It is amazing to note how the ego devours people, sapping their energy, turning them into blind brutes, while they themselves believe that they are really living a great life. This is the fatal delusion in which human beings often dwell. Only those who have glimpsed the truth of their inner divinity are likely to escape this milieu of death.

\section{AUM: THE ETERNAL, CREATIVE REVERBERATION}

In the Kurushetra war, conchs play not only a battle announcement role but also a very significant symbolic role. The war is declared by sounding conchs. Suddenly, there is a riot of conch sounds, conchs vying each other, in the battlefield. Conchs are not man-made, but the product of the ocean and are mere empty shells. However, they can transform human breath into mighty sounds. Conchs thus represent human words, the condensation of their breath. In the final analysis, all known realities can be reduced to, and are acknowledged as mere vibrations $\left(e=\mathrm{mc}^{2}\right)$. Hinduism considers Aum, the eternal sound, as the source and the sum of everything. Every sound we produce is the echo of the eternal Aum. The sound of the Kaurava conchs represents the vibrations of maya (delusion), ignorance and the ego. But the sound of the Pandava conchs represents the divine sound of Aum intoned by yogis. We are told that 
Krishna blew his Panchajanya; Arjuna blew Devadatta, while Bhima, terrible in action, blew the great conch horn Paundra. King Yudhishthira, son of Kunti, blew Anantavijaya; Nakula and Sahadeva blew Sughosha and Manipushpaka $(1: 15,16)$.

These names are highly symbolic. Panchajanya (five victories) points to the spiritual victory of Aum over the five elements (bhutas), mastery over the five bodies (koshas) and control over the five sense organs (indriyas). Devadatta (God-given) proclaims Aum as the key to liberation given by God himself to human beings. Paundra (mighty sound) announces Aum as the supreme Word of Power. Anantavijaya (unending victory) states the effect of the recitation (japa) of Aum. Sughosha (great/excellent sound) makes known the ecstatic experience of those who recite Aum. Manipushpaka (could mean jewelled bracelet, flowery mind, aerial chariot of the mind, and so on). Through the recitation of Aum, the mind is transformed into a precious jewel. At the recitation of Aum the mind blossoms like a flower. Aum causes the mind to open up and soar in the Chidakasha (sky of consciousness). The sounding of the conchs thus symbolically portrays the yogi, engaged in the interior battle, who has brought under control all his faculties in meditation and united them in the constant invocation of Aum, causing it to vibrate throughout his being. By its continual intonation, Aum resounds throughout the "sky" (mind) and "earth" (body) of the yogi, and bursts apart the hearts of all the foes of the self, for the consciousness arising from its invocation first renders them powerless, and then annihilates them (1:19).

\section{DISCERNMENT: THE MESSAGE OF THE BHAGAVAD-GITA}

As mentioned earlier, the core of the Bhagavad-Gita is the enlightening response to the confused and puzzled Arjuna, who was unsuccessful in discerning his svadharma (personal duty). Arjuna appeals to Krishna:

With my very being tainted by the vice of faint-heartedness and my mind puzzled with regard to duty, I am asking you. Tell me that which is decidedly good; I am your disciple. Pray, instruct me, who have put myself into your hand (2:7).

Most of the commentators, including Mahatma Gandhi, were of the opinion that the Bhagavad-Gita is not concerned with actual warfare and opted for allegorical or metaphorical interpretation. In his commentary on the Gita, Gandhi interpreted the battle as "an allegory in which the battlefield is the soul and Arjuna, man's higher impulses struggling against evil". One of 
the great modern Indian mystics, Ramakrishna Paramahamsa, stated that the essential message of the Gita can be obtained by repeating the word several times: one begins by saying "gita, gita, gita", but then one finds oneself saying "ta-gi, ta-gi, ta-gi". Tyagi in Sanskrit means one who has renounced everything for God (Nikhilananda).

\section{ARJUNA: THE IMAGE OF HUMAN PREDICAMENT}

The Bhagavad-Gita presents Arjuna as an embodiment of the human predicament as he enquires: "How Krishna, shall I fight Bhisma and Drona with arrows on the battle-field? They are worthy of deepest reverence." (2:4) Bhishma is his grandfather and Drona, his beloved teacher. He continues:

We do not know which is preferable for us - to fight or not to fight; nor do we know whether we shall win or whether they will conquer us. Those very sons of Dhrtharashtra, killing whom, we do not even wish to live, stand in the enemy ranks. (2:6).

By way of clearing the confusion of Arjuna, Lord Krishna first tries to shed some light on the mental state of Arjuna who was arguing with Krishna like a learned person. However, Krishna points out that his sorrow and grief indicate that he is not yet wise, because "wise men do not sorrow over the living or the dead" (2:11). Krishna again clarifies that, for a wise man, pain and pleasure are alike (2:15). This is because

[t]he unreal has no existence, and the real never ceases to be; the reality of both has thus been perceived by the seers of the truth (2:16).

Krishna clarifies to Arjuna that the soul is eternal, omnipresent, immovable, constant and everlasting (2:24); so there is no need for him to mourn for this transitory body which is designed to perish sooner or later.

Krishna reminds Arjuna of the duty that is assigned to him as a soldier: "... there is nothing more welcome for a man of the warrior class than a righteous war" (2:31). Krishna continues: "Now, if you refuse to fight this righteous war, then, shrinking your duty and losing your reputation, you will incur $\sin$ " (2:33). According to Krishna, Arjuna, being a warrior by profession, should be ready to accept both life and death:

Die, and you will win heaven; conquer, and you will enjoy sovereignty of the earth; therefore, stand up, Arjuna, determined to fight. Treating alike victory and defeat, gain and loss, pleasure and pain, get ready for the fight, then; fighting thus you will not incur $\sin (2: 37-38)$. 


\section{ATTACHMENT: THE CAUSE OF CONFUSION}

Lord Krishna helps Arjuna to discern the true cause of suffering. "... those who are deeply attached to pleasure and worldly power cannot attain the determinate intellect concentrated on God" (2:44). Krishna clearly instructs Arjuna:

Your right is to work only, but never to the fruit thereof. Be not instrumental in making your actions bear fruit, nor let your attachment be to inaction. Arjuna, perform your duties established in yoga, renouncing attachment, and even-temperament in success and failure; evenness of temper is called yoga (2:47-48).

For a person who has attained equanimity, even the scriptures are useless. Krishna makes a most daring statement:

A Brahman, who has attained enlightenment, has the same use of all the Vedas as one who stands at the brink of the sheet of water overflowing on all sides has for a small reservoir of water (2:46).

He assures Arjuna that, "he who has given up all desires and move free from attachment, egoism and thirst for enjoyment attains peace" (2:71).

\section{TO ACT IS BOTH DIVINE AND HUMAN}

Krishna reminds Arjuna of his obligation to act:

Surely none can ever remain inactive even for a moment; for everyone is helplessly driven to action by nature-born qualities. He who outwardly restraining the organs of sense and action, sits mentally dwelling on the objects of senses, that man of deluded intellect is called a hypocrite (3:5-6).

However, Krishna points towards the possibility of acting without any attachment, which is sacrifice (3:9). Krishna points towards God as the best example for this kind of "perfect action". According to Krishna, God's creative activity in itself was a sacrifice:

Having created mankind with sacrifice at the beginning of creation the Creator, Brahma, said to them, 'You shall prosper by this; may this yield the enjoyment you seek' (3:10).

Arjuna is made to understand that every act of the Creator is a sacrifice. The world has originated, is sustained and supported through sacrifice. Our vocation as human beings is to collaborate consciously and actively in this ongoing divine sacrifice: 
Foster the gods through sacrifice, and let the gods be gracious to you. Each fostering the other disinterestedly, you will attain the highest good. (3:11).

Feed gods and get fed by gods - be a conscious collaborator in this eternal feeding-chain. Krishna calls those who refuse to engage in selfsacrificing activities, thieves (3:12). Acting with a desire for its fruit is a disgraceful act like a cow that drinks its own milk. It already had its share of milk as a calf and now her milk is for her calf. Krishna demands from Arjuna action without attachment, seeking only the maintenance of the world order (3:25).

\section{BE MASTERS, NOT SLAVES OF NATURE}

Krishna instructs Arjuna about the inherent gunas (qualities) of prakrti (nature/matter). Being material, we have inherited those qualities. Yet, we are not destined to be governed by those natural qualities (3:28). However, having transcended the control of nature does not give anyone the right to scorn the ignorant, who are still under its yoke. The liberated should be compassionate towards them and should be willing to help them:

Those who are completely deluded by the gunas of prakrti remain attached to those gunas and actions; the man of perfect knowledge should not unsettle the mind of those insufficiently knowing fools. (3:30).

It is the forgetfulness of the past that makes people proud. Presenting himself as an example; Krishna clarifies the difference between an enlightened person and an ordinary person: "Arjuna, you and I have passed through many births, I remember them all; you do not remember." (4:5). It is the forgetfulness of the past that makes people proud, arrogant, and cold towards others. Krishna then reveals another fact about action to Arjuna: "He who sees inaction in action, and action in inaction, is wise among men; he is a yogi, who has performed all actions." (4:18). Running away from action or finding false justification for our failures to act will not make us wise or masters of our nature:

On the earth there is no purifier as great as Knowledge; he who has attained purity of heart through a prolonged practice of karma yoga (action without attachment) automatically sees the light of Truth in the self in course of time, assures Krishna (4:38). 


\section{BE THE WITNESS: THE ROYAL PATH TO DISCERNMENT}

In an attempt to lead him to the royal path of discernment, Krishna says to Arjuna:

He who acts offering all actions to God, and shaking off attachment, remains untouched by sin, as the lotus leaf by water (5:10).

The wise look with the same eye on a Brahman endowed with learning and culture, a cow, an elephant, dog, and a pariah too (5:18).

According to Krishna, when the disciplined mind of a person is firmly established in God and is actively engaged in the service of all beings, it attains Brahma, who is all peace $(5: 25)$. He will be in a position to regard stone, earth and gold alike (6:8):

He who looks upon well-wishers and neutrals as well as mediators, friends and foes, relatives and objects of hatred, the virtuous and the sinful with the same eye, stands supreme (6:9).

This state of mind is attainable if one could perceive the universal self to be present in all beings, and all beings existing within it (6:30):

Arjuna, he who looks on all as one, on the analogy of his own self, and looks upon the joy and sorrow of all with a similar eye, - such a yogi is deemed the highest of all (6:32).

The awareness that all beings have emerged from the same source and their destination is also the same will enable one to overcome one's irrational responses of attachment and aversion (7:6). Krishna offers Arjuna an easy way to reach this state of equilibrium through bhakti (devotion):

Arjuna, whatever you do, whatever you eat, whatever you offer as oblation to the sacred fire, whatever you bestow as a gift, whatever you do by way of penance, offer it all to me (9:27).

As a powerful means to convince his beloved disciple, Krishna is transfigured in front of Arjuna and reveals his glorious divine form with an effulgence of a thousand suns where he could see the universe, its past, present and future, gods and goddesses, even the terrible conclusion of the battle they are about to wage and the looming mass destruction. Krishna reveals himself as the embodiment of Time (kala) and warns him:

Even without you all these warriors arrayed in the enemy's camp must die ... These warriors stand already slain by me; be you only an instrument, Arjuna. Do you kill Drona, and Bhishma, Jayadratha 
and Karna and even other brave warriors; who stand already killed by me; fear not. You will surely conquer the enemies in this war; therefore, fight (11:32-34).

Krishna assures Arjuna that

[t]he Spirit dwelling in this body, is really the same as the Supreme. $\mathrm{He}$ has been spoken of as the Witness, the true guide, the Sustainer of all, the Experiencer (as the embodied soul), the Overlord and the absolute as well (13:22).

When a person is capable of watching everything that happens within and around him dispassionately and acting with an attitude of detachment, s/he has reached sthithaprajna (equanimity) and attained Samadhi (liberation). According to Krishna,

He alone really sees, who sees all actions being performed in every way by prakrti (nature) alone, and the Self as the non-doer (13:29).

When light and discernment dawn in this body, as well as in the mind and senses ... (14:11),

one will be free from every turbulence of mind and body:

He who sitting like a witness, is not disturbed by gunas, and who, knowing that the gunas alone move among gunas, remains established in identity with God, and never falls off from that state (14:23).

Krishna's final warning is even more authoritative: "If taking your stand on egoism, you think, 'I will not fight', vain is this resolve of yours; nature will drive you to the act. That action too which you are not willing to undertake through ignorance, - bound by your own duty born of your nature, you will helplessly perform." (18:59-60). After his extensive and magnificent discourse on discernment, Krishna leaves everything to the discretion of Arjuna saying: "Thus has this wisdom, more secret than secrecy itself, been imparted to you by me. Fully pondering it, do as you like" (18:63). Being fully enlightened, Arjuna responds:

Krishna, by your grace my delusion has fled and wisdom has been gained by me. I stand shorn of all doubts. I will do your bidding. (18:73).

At last, a happy ending to a long walk to discernment. 


\section{RELEVANCE OF GITA'S VISION IN BIBLICAL CONTEXT}

In a context that explores the biblical roots of discernment, one may reflect on what would be the role and relevance of a study on discernment according to a non-Christian scripture such as the Bhagavad Gita. The answer is quite simple. Such an exploration is not only relevant, but also exceptionally helpful and enormously valuable for a deeper understanding of this concept from a fundamentally different perspective. Discernment is after all not merely a Christian concern, but also a perennial human obsession. As Celia Kourie rightly concludes in her article in this volume, an inter-scriptural soul-searching will "contribute to greater insights into the many-faceted splendor of the Ultimate". In our multicultural society, no religion or society can isolate or insulate itself and survive like a living fossil. According to Kourie, tapping into the wisdom of other cultures and religions for mutual understanding and enrichment should be our way forward. For example, the literary style of the Bhagavad Gita, which demands, necessitates, and provides room for any number of commentaries and interpretations, becomes an eye-opener and a challenge to those who support and practise scriptural idolatry that takes away the growth potential, plasticity, freedom, and the life of their Sacred Scriptures. A generous attitude will keep our windows open to new perspectives and doors to new dives into the everdeepening realms of divine revelations. Scriptural idolatry can blind people, sapping their energy, turning them into bullies while believing themselves to be defenders of orthodoxy and truth.

An occasional glance into analogous concepts found in other religions will, in addition to revealing the complementarities and mutual agreements, save us from forgetting the past that makes people proud, arrogant, and cold towards others. Moreover, as Krishna instructs Arjuna, such comparisons can be regarded as part of our intellectual discernment cum scriptural validation (16:24). For example, the Bhagavad Gita treats sacrifice - a concept that people often demarcate as a Christian contribution to the milieu of spirituality - from a radically different perspective. Krishna tells Arjuna that acting without attachment is in itself a sacrifice (3:9). He points towards God as the best example for this kind of "perfect action". According to Krishna, God's creative activity was in itself a sacrifice. The world has originated, sustained and is supported through sacrifice. Our vocation as human beings is to collaborate consciously, actively and collectively in this ongoing divine sacrifice. 


\section{CONCLUSION}

Even a casual reading of the Bhagavad-Gita will convince a person that our ancestors have left a great treasury of wisdom for us, their posterity, from which to derive some benefit and become enlightened. Thinking that it belongs to the Hindu Sacred Scripture, people of other religions and cultures need not be too nervous about the Gita, as it is part of the epic Mahabharatha (a part of smrti [reflections]) and does not belong to Vedas or Upanishads (shruti [revelations]). The Bhagavad-Gita is an intelligent response to a perennial human predicament which other religions and philosophies tried to resolve in their own way. As the Veda would state, Ekam sat vipra behudha vadanti (Reality is one, learned people speak of it differently) (Rigveda 1:164, 46). The superiority-inferiority complexes emerging from blind egos will not benefit humanity. Any answer given, any discovery made in any corner of the world belongs to the entire human species and to the entire universe. Therefore, turning a blind eye towards, or refusing to open up to the available truths and resources is a crime against oneself, others and God. According to the Gita, there are three margas (ways) available to us to attain freedom, namely karma (action), bhakthi (devotion) and jnana (knowledge). They are not watertight compartments. They are merely three stages of the one and the same path, the goal being transcendence from the servitude of the known and the unknown. Transcendence is a human potential, even though all have nama-rupa (name and form); only those who attempt to realise this potential can be considered truly human in its proper sense. The proud and the arrogant are still struggling in the pit of ignorance, self-deception and brutality. What they need is the discerning capacity disseminated by the Bhagavad-Gita!

\section{BIBLIOGRAPHY}

Chaturvedi, B.

2006. The Mahabharata: An inquiry in the human condition. New Delhi: Orient Longman.

FREIN, B.

2012. Fundamentalism and narrative approaches to the Gospels. Biblical Theology Bulletin 22:12-18.

GANDHI, M.K.

[s.a.] Influence of Bhagavad Gita. [Online.] Retrieved from: http://en.wikipedia. org/wiki/Influence_of_Bhagavad_Gita [20 November 2012].

GanGULI, K.M.

[s.a.] Mahabharata of Vyasa. [Online.] Retrieved from: www.mahabharataonline. com/translation/mahabharata_01002.php. [20 November 2012]. 
GoYANDAKA, J.

1994. The Bhagavad-Gita or The Song Divine. Gorakhpur: Govind Bhavan Karyalaya.

GRIFFITH, R.T.H.

[s.a.] Rigveda. [Online.] Retrieved from: http://www.sacred-texts.com/hin/ rigveda/index.htm [20 November 2012].

GuruparanANDA, S.

[s.a.] Katha Upanishad. [Online.] Retrieved from: http://archive.org/details/ KathaUpanishad [20 November 2012].

KAJI, D.S.

2001. Common sense about uncommon wisdom: Ancient teachings of Vedanta. Honesdale: The Himalayan Institute Press.

KnAPP, S.

[s.a.] Vedic Culture/Hinduism: A short introduction. [Online.] Retrieved from: www.stephen-knapp.com/vedic_culture_hinduism_a_short_introduction.htm [20 November 2012].

KRISHNANANDA, S.

[s.a.] Mundakopanishad. [Online.] Retrieved from: http://www.swamikrishnananda.org/mundaka_0.html [20 November 2012].

NADUMURI, J.

2010. Bharatha. [Online.] Retrieved from: http://ancientvoice.wikidot.com/ mbh:bharata [20 November 2012].

NikHiLANANDA, S.

[s.a.] The Gospel of Sri Ramakrishna. [Online.] Retrieved from: www.belurmath. org/gospel/index.htm [20 November 2012].

RAMACHARAKA, Y.

2010. The Bhagavad Gita's teachings on spiritual discernment. Whitefish: Kessinger Publishing.

WIKIPEDIA

[s.a.] Mahabharata. [Online.] Retrieved from: http://en.wikipedia.org/wiki/ Mahabharata [20 November 2012].

Keywords

Discernment

Detachment

Liberation

Equanimity

Karma
Trefwoorde

Onderskeiding

Afstand

Bevryding

Onversteurdheid

Karma 